\section{Sweetpotato Periderm Components Inhibit In Vitro Growth of Root Rotting Fungi}

\author{
Howard F. Harrison Jr. ${ }^{1}$ and Joseph K. Peterson \\ U.S. Vegetable Laboratory, U.S. Department of Agriculture, Agricultural \\ Research Service, 2875 Savannah Highway, Charleston, SC 29414 \\ Christopher A. Clark ${ }^{2}$ \\ Department of Plant Pathology and Crop Physiology, Louisiana State \\ University, Baton Rouge, LA 70803
}

\author{
Maurice E. Snook ${ }^{3}$ \\ Russell Research Center, University of Georgia, Athens, GA 30604
}

Additional index words. Fusarium oxysporum, Fusarium solani, Lasiodiplodia theobromae, Rhizopus stolonifer, Ipomoea batatas, disease resistance, fungicidal activity, postharvest

\begin{abstract}
Sweetpotato [Ipomoea batatas (L.) Lam.] periderm components were tested for their effect on four fungi that infect sweetpotato roots: Fusarium oxysporum Schlecht. f. sp. batatas (Wollenw.) Snyd. \& Hans. and F. solani (Sacc.) Mart., both of which cause stem and root disease; and Lasiodiplodea theobromae (Pat.) Griffon \& Maubl. and Rhizopus stolonifer (Ehr. ex Fr.) Lind., both of which cause storage root disease. Sequential extracts of 'Regal' sweetpotato periderm with hexane, methanol, and $50 \%$ methanol were inhibitory to the four fungi when incorporated into potato dextrose agar medium in petri dish bioassays. The methanol and $\mathbf{5 0 \%}$ methanol extracts were much more active than the hexane extract and were combined for further study. Sephadex LH-20 column chromatography of the combined extracts, followed by bioassay with $F$. oxysporum indicated that the most inhibitory fraction contained the least polar components of the extract. Resin glycosides isolated from 'Regal' periderm inhibited $F$. oxysporum, but the glycosides exhibited little concentration effect and were not as active on a tissue weight basis as other components. Periderm extracts from 10 sweetpotato clones exhibited large differences in inhibitory activity in bioassays with the four fungi. The sensitivity of the fungi to inhibition by the periderm extracts suggests that periderm components may provide protection against soil pathogens, but a relationship between such components and disease resistance was not established.
\end{abstract}

Sweetpotato has been ranked among the top 10 food crops worldwide on a weight basis (Clark and Moyer, 1988), and is among the top five in the tropics. In temperate regions, sweetpotatoes are typically stored for several months between growing seasons, but the crop is usually harvested throughout the growing season and consumed immediately after harvest in the tropics, where several rapidly developing postharvest diseases prevent suc-

Received for publication 9 Feb. 2000. Accepted for publication 20 Nov. 2000. The cost of publishing this paper was defrayed in part by the payment of page charges. Under postal regulations, this paper must be hereby marked advertisement solely to indicate this fact. Mention of a proprietary product does not constitute a guarantee or warranty of the product by the U.S. Dept. of Agriculture and does not imply its approval to the exclusion of other products that may be suitable. The cost of publishing this paper was defrayed in part by the payment of page charges. Under postal regulations, this paper therefore must be hereby marked advertisement solely to indicate this fact.

${ }^{1}$ Research Agronomist and Research Plant Physiologist. E-mail address: howardh@awod.com

${ }^{2}$ Plant Pathologist.

${ }^{3}$ Chemist. cessful long-term storage. Postharvest disease in sweetpotato is generally referred to as storage rot, and many storage rots are incited by fungi. The fungi, Fusarium oxysporum $\mathrm{f}$. sp. batatas (FOB), Fusarium solani (FS), Lasiodiplodea theobromae (LT), and Rhizopus stolonifer (RS) are important sweetpotato postharvest pathogens that cause rotting of storage roots. FOB and FS also cause root and stem disease to sweetpotatoes in the field. Differences among sweetpotato genotypes in disease resistance have been reported against all four pathogens (Campbell and Collins, 1987; Clark et al., 1986, 1992; Clark and Hoy, 1994; Collins and Nielson, 1976; Jenkins, 1981).

Although development of disease-resistant clones has been a major emphasis of sweetpotato breeding, and several highly resistant cultivars have been developed, there are few reports on the mechanisms of resistance. Phytoalexins are antimicrobial compounds of low molecular weight that are synthesized and accumulated in plants after exposure to pathogens (Peterson and Harrison, 1992). The occurrence of potential phytolalexins in response to wounding or microbial infection has been reported in sweetpotato (Clark et al., 1981; Hyodao et al., 1969; Kim and Uritani, 1974), and they are thought to be important in disease resistance. Japanese researchers first reported that, after infection with Sclerotium bataticola (Taub.), a phytoalexin was produced by sweetpotatoes that was later identified as a furanoterpenoid compound and named ipomoeamarone (Schneider et al., 1984). Wilson et al. (1971) identified 15 additional furanoterpenoids from sweetpotato, and a biogenetic scheme of sweetpotato stress metabolites, including structures and nomenclatures of $\approx 30$ compounds, was prepared by Schneider et al. (1984). Ipomoeamarone was the most abundant metabolite; the others were thought to be precursors or further conversion products of ipomoeamarone. Antimicrobial, fungistatic, and antihelminthic properties were established for ipomoeamarone and related metabolites (Uritani and Akazawa, 1954; Wilson, 1973). Terpene chemistry appears to be important in induced sweetpotato defense against pathogens; however, the furanoterpenoid compounds are toxic to mammals, and sweetpotatoes with high levels are not suitable for consumption by humans or livestock (Wilson, 1973; Wilson et al., 1971).

Phenolic compounds, particularly chlorogenic acids, also accumulate in infected sweetpotato tissues (Uritani, 1967; Uritani and Miyano, 1955) and nematode-resistant sweetpotatoes accumulate higher levels of these compounds than do nonresistant sweetpotatoes (Gapasin et al., 1988). Phenolics have been implicated as contributors to induced resistance to diseases, but no quantitative evidence has been published on their production or biological role in sweetpotato.

The sweetpotato periderm is the protective outer layer of storage and feeder roots, and consists of both living and dead cells. Constituent components of sweetpotato periderm tissue are important in the allelopathic inhibition of weeds (Harrison and Peterson, 1993; Peterson and Harrison, 1991); the most important of these is a group of complex, cyclic sugar-fatty acid esters referred to as resin glycosides (Peterson and Harrison, 1991; Peterson et al., 1999). Similar glycosides contribute to allelopathy in the related species, Ipomoea tricolor Cav. (Anaya et al., 1990). The levels of resin glycosides varied from $0 \%$ to $3.4 \%$ of periderm dry weight among 10 sweetpotato clones, and resin glycoside content was correlated with their inhibition of proso millet (Panicum milliaceum L.) seed germination in a bioassay and yellow nutsedge (Cyperus esculentus L.) growth in a greenhouse experiment (Peterson et al., 1999). Resin glycosides incorporated into an artificial diet inhibited the growth of the diamondback moth (Plutella xylostella $\mathrm{L}$.), indicating that the compound may also contribute to insect resistance (Peterson et al., 1998).

The primary objective of this study was to investigate the effect of sweetpotato periderm components on the growth of four fungi that incite root disease in sweetpotato to determine their potential role in protection against those pathogens. Additional objectives were to de- 
termine the most inhibitory extract or chromatographic fractions in a FOB bioassay and to compare the fungicidal activity of periderm extracts from genetically different sweetpotato clones.

\section{Materials and Methods}

Fungal bioassay procedures. Isolates of pathogenic strains of the four fungi were obtained from naturally infected roots or vines of sweetpotato from Louisiana and maintained on silica gel at $-20^{\circ} \mathrm{C}$. Inoculum for the fungus bioassay experiments was prepared by mass transferring the cultures onto potato dextrose agar medium (PDA) (BBL Potato Dextrose Agar; Beckton Dickinson Microbiology Systems, Cockeysville, Md.) plates, and incubating in darkness at $25^{\circ} \mathrm{C}$ for 2 to 3 weeks. Test fractions of periderm extracts or chromatographic fractions were pipetted into $50-\mathrm{mL}$ beakers and dried at $50{ }^{\circ} \mathrm{C}$ until all solvents were evaporated. The beakers were then placed in a high-efficiency particle-arresting (HEPA) filtered transfer hood, sterilized with a $70 \%$ ethanol spray, and dried at room temperature. Warm, sterile PDA was poured into the beaker and the test fraction was incorporated into the medium by scraping the dried extract from the beaker and vigorously stirring with a flamed stainless steel spatula. A $1.5-\mathrm{mL}$ aliquot of PDA containing the test extract was pipetted into a $35 \times 10-\mathrm{mm}$ petri dish and allowed to gel. Since all solvents were evaporated completely before adding PDA, no solvent was included in the controls; however, control beakers were sterilized with $70 \%$ ethanol and dried. Small segments of mycelium $(\approx 1 \mathrm{~mm}$ in diameter), taken from the same area of the inoculum plate to ensure uniformity in age, were transferred to the center of each petri dish using a flamed dissecting needle. Petri dishes were sealed with paraffin film and placed in a dark incubator at $25^{\circ} \mathrm{C}$ and incubated for 48 , 48, 24, and $18 \mathrm{~h}$ for FOB, FS, LT, and RS, respectively. The diameter of the fungal colony was measured using a caliper at the end of the incubation period.

Periderm extraction procedure. Periderm tissue was removed from field-grown sweetpotato storage roots by scraping with a scalpel. The periderm was dried at $50{ }^{\circ} \mathrm{C}$, ground to pass through a $0.85-\mathrm{mm}$ screen, and stored at $-20{ }^{\circ} \mathrm{C}$ until used. The periderm tissue was extracted by the following procedure: solvent was added to tissue at $15 \mathrm{~mL} \cdot \mathrm{g}^{-1}$ in a $50-\mathrm{mL}$ polyethylene centrifuge tube; the tissue was suspended on a vortex mixer for $20 \mathrm{~s}$; and the tube was then placed in an ice water bath, sonicated for $20 \mathrm{~min}$, and centrifuged to precipitate the solids. This procedure was repeated twice for each of the extraction solvents, hexane, methanol, and $50 \%$ aqueous methanol, in a sequential extraction scheme. Supernatants from extractions with the same solvent were combined to make an extract and condensed under vacuum for use in fungal bioassays.

'Regal' periderm crude extracts. 'Regal' sweetpotato periderm was extracted and the three crude extracts were bioassayed for their effect on the growth of the four fungi as described above. Treatments for each species included a PDA control and three concentrations, 25, 50, and $100 \mathrm{mg} \cdot \mathrm{mL}^{-1}$ (based on weight of dried periderm extracted per volume of PDA), for each of the extracts. The experiment was arranged in a completely random design with five replicates, it was repeated using separate extracts, and data from the three experiments were combined for analysis of variance (ANOVA).

Liquid chromatography fractions and purified periderm resin glycosides. Methanol and $50 \%$ aqueous methanol extracts of 'Regal' periderm were obtained using the procedures described above and combined for chromatography. The combined extract was initially separated using the Sephadex LH-20 (Sigma Chemical Co., St. Louis) low-pressure column chromatography procedure used in previous studies (Peterson and Harrison, 1991). This procedure separates the extract into five fractions based on polarity. The fractions were tested for their activity in the FOB bioassay described above at a concentration (based on weight of dried periderm extracted per volume of PDA) of $200 \mathrm{mg} \cdot \mathrm{mL}^{-1}$.

A mixture of resin glycoside constituents of 'Regal' periderm was purified from Sephadex LH-20 column chromatography fraction three using a previously described high pressure liquid chromatography procedure (Peterson and Harrison, 1991). The fraction containing the resin glycosides was dried, and the glycosides were weighed, dissolved in methanol, and tested in the FOB bioassay at concentrations of $0.0 .125,0.25,0.5,1.0$, and $2.0 \mathrm{mg} \cdot \mathrm{mL}^{-1}$. Both of these experiments were arranged in a completely random design with five replicates and were repeated using separate extracts and fractions from separate chromatography procedures. Data from the two repeats of the liquid chromatography experiment were combined for ANOVA, and standard deviations of the means and linear regression were determined for combined data from two repeats of the resin glycoside concentration-response experiment.

Methanol and aqueous methanol extracts of ten sweetpotato clones. Ten sweetpotato cultivars and breeding clones, 'Beauregard',
'Centennial', 'Excel', 'Jewel', 'PI 399163', 'Regal', 'SC 1149-19', 'Sumor', 'Tinian', and 'Travis', were selected based on their genetic variability and reported variation in disease resistance. Periderm tissue from field-grown storage roots of each clone was collected and sequentially extracted as described above. The methanol and 50\% methanol extracts were combined and tested against the four pathogens at concentrations equivalent to periderm extracted at $50,50,10$, and $25 \mathrm{mg} \cdot \mathrm{mL}^{-1} \mathrm{PDA}$ for FOB, FS, LT, and RS, respectively, and controls were grown on PDA. The experiment was arranged in a completely randomized design with five replications, repeated, and data from the two repeats were combined for ANOVA.

\section{Results}

'Regal' peridermextracts. All 'Regal' periderm extracts were inhibitory to the growth of the four fungi at all concentrations (Table 1). The hexane extract was least inhibitory and there was little concentration effect. The components present in the hexane extract were oily in appearance and floated to the surface of the gelled PDA medium. This film on the surface of the medium may have acted as a physical barrier, slowing fungal growth. Since the hexane fraction was much less inhibitory to all fungi than the more polar extracts it was not considered to be fungicidal and was discarded in subsequent studies. The preliminary extraction with hexane was useful in removing periderm lipids that may interfere with extraction of less polar constituents. The methanol extract was most inhibitory and showed a strong concentration effect. The $50 \%$ methanol extract was somewhat less inhibitory than the methanol extract, but this fraction also exhibited a strong concentration effect. The methanol and 50\% methanol extracts were combined for subsequent studies; whereas methanol extracts contained the least polar of the remaining soluble periderm components, and $50 \%$ aqueous methanol extracts the more polar components, many components with intermediate polarity were probably extracted by both solvents. The fungi differ in their sensitivity to sweetpotato periderm components.

Table 1. Diameter of colonies of four sweetpotato root rotting fungi in response to 'Regal' sweetpotato periderm extracts incorporated into potato dextrose agar medium.

\begin{tabular}{|c|c|c|c|c|c|}
\hline \multirow{2}{*}{$\begin{array}{l}\text { Extraction } \\
\text { solvent }\end{array}$} & \multirow{2}{*}{$\begin{array}{c}\text { Extract concn }{ }^{\mathrm{z}} \\
\left(\mathrm{mg} \cdot \mathrm{mL}^{-1}\right)\end{array}$} & \multicolumn{4}{|c|}{ Diam of colony $(\mathrm{mm})$} \\
\hline & & $\mathrm{FOB}^{\mathrm{y}}$ & FS & LT & $\mathrm{RS}$ \\
\hline Control & --- & 18.3 & 15.2 & 18.8 & 30.2 \\
\hline \multirow[t]{3}{*}{ Hexane } & 25 & 16.5 & 14.5 & 15.7 & 28.8 \\
\hline & 50 & 16.2 & 14.2 & 16.0 & 28.0 \\
\hline & 100 & 15.8 & 13.0 & 14.7 & 28.0 \\
\hline \multirow[t]{3}{*}{ Methanol } & 25 & 13.0 & 8.5 & 0.5 & 22.2 \\
\hline & 50 & 11.2 & 7.2 & 0 & 18.7 \\
\hline & 100 & 10.5 & 6.3 & 0 & 15.7 \\
\hline \multirow[t]{3}{*}{$50 \%$ Methanol } & 25 & 15.8 & 13.0 & 5.8 & 24.8 \\
\hline & 50 & 14.8 & 12.0 & 4.0 & 20.3 \\
\hline & 100 & 13.3 & 10.3 & 4.0 & 16.5 \\
\hline $\operatorname{LSD}_{0.05}{ }^{\mathrm{x}}$ & & 0.7 & 0.7 & 0.9 & 1.0 \\
\hline
\end{tabular}

$\overline{{ }^{2} \text { Extract concentration based on amount of freeze-dried periderm extracted per volume potato }}$ dextrose agar medium.

${ }^{\mathrm{y}} \mathrm{FOB}=$ Fusarium oxysporum $\mathrm{f}$. $\mathrm{sp}$. batatas, $\mathrm{FS}=$ Fusarium solani, $\mathrm{LT}=$ Lasiodiplodia theobromea, $\mathrm{RS}=$ Rhyzopus stolonifer .

xProtected LSD at $P=0.05$ for comparing means within fungal species. 
LT was most sensitive, and its growth was strongly inhibited by all concentrations of both extracts.

Column chromatography fractions and purified periderm resin glycosides of 'Regal' periderm extract. The Sephadex LH-20 column procedure was used to separate the periderm components in the combined methanol and $50 \%$ methanol extracts into groups based on their polarity. The least polar components were eluted first, the most polar components last. All of the column fractions except fraction five inhibited the growth of FOB (Table 2 ). The least polar constituents in fraction one were most inhibitory, followed in order of activity by fractions three, two, and four. The resin glycosides present in 'Regal' periderm that accounted for most of the plant growth inhibition (Peterson and Harrison, 1991) elute in Sephadex LH-20 column fraction three. Although they inhibited FOB at all concentrations tested (Fig. 1), there was little concentration effect as indicated by a lack of a significant $R^{2}$ value (data not shown).

Combined methanol and 50\% methanol extracts of the periderm of 10 sweetpotato clones. The fungicidal activity of the combined methanol and $50 \%$ aqueous methanol periderm extracts varied greatly for the 10 sweetpotato clones (Table 3). The concentrations used in this experiment were chosen based on the results of preliminary experiments (data not presented) to determine the optimum concentration for detecting differences between cultivars. As observed in the previous experiment (Table 1), LT was most sensitive to the extracts. Its growth was inhibited more at an extract concentration of $10 \mathrm{mg} \cdot \mathrm{mL}^{-1}$ than were those of the Fusarium species were at $50 \mathrm{mg} \cdot \mathrm{mL}^{-1}$. Although the four fungi varied in sensitivity to inhibition by the extracts, the relative ranking of the clones was fairly consistent. Generally, the clones could be separated into three groups for their effects on FOB and RS: low inhibition ('PI 399163' and 'Tinian'), intermediate inhibition ('SC 1149-19', 'Jewel', 'Centennial', and 'Travis'), and high inhibition ('Beauregard', 'Regal', 'Sumor', and 'Excel'). The grouping was similar for FS, except that 'Jewel' was among the least inhibitory and 'Beauregard' was intermediate. Periderm extracts of all clones were highly inhibitory to LT, but extracts of 'Regal', 'Sumor', and 'Excel' were most inhibitory.

Table 2. Diameter of colonies of Fusarium oxysporum f. sp. batatas in response to sephadex column chromatography fractions of 'Regal' periderm extract in potato dextrose agar medium.

\begin{tabular}{lcc}
\hline \hline Fraction & $\begin{array}{c}\text { Elution } \\
\text { solvent }^{2}\end{array}$ & $\begin{array}{c}\text { Diam of } \\
\text { colony }^{\mathrm{y}}(\mathrm{mm})\end{array}$ \\
\hline Control & --- & $19.4 \mathrm{a}$ \\
1 & $1 \mathrm{MeOH}: 20 \mathrm{EtOAc}$ & $12.9 \mathrm{~d}$ \\
2 & $1 \mathrm{MeOH}: 20 \mathrm{EtOAc}$ & $15.5 \mathrm{bc}$ \\
3 & $1 \mathrm{MeOH}: 2 \mathrm{EtOAc}$ & $14.6 \mathrm{c}$ \\
4 & $1 \mathrm{MeOH}: 2 \mathrm{EtOAc}$ & $16.0 \mathrm{~b}$ \\
5 & $100 \% \mathrm{MeOH}$ & $19.0 \mathrm{a}$ \\
\hline
\end{tabular}

${ }^{2}$ EtOAc $=$ ethyl acetate, $\mathrm{MeOH}=$ methanol.

${ }^{\mathrm{y}}$ Mean separation by Duncan's multiple range test, $P \leq 0.05$.

\section{Discussion}

These studies indicate that components of sweetpotato periderm [when incorporated into an artificial medium] are highly inhibitory to the growth of four root-rotting fungi. The most sensitive species, LT, was inhibited at lower concentrations of the methanol extract (Tables 1 and 3) than were the most sensitive weed species in previously reported seed germination or root growth bioassays (Harrison and Peterson, 1993; Peterson and Harrison, 1991; Peterson et al., 1999). The periderm tissue that forms the outer surface of sweetpotato storage and fleshy feeder roots is continually sloughed off and reformed during root growth (Steinbauer and Kushman, 1971). The sensitivity of the fungi to inhibition by periderm constituents suggests that the release of inhibitors into the soil during root growth may contribute to the defense of sweetpotato roots against infection. However, further studies are needed to demonstrate this effect under natural conditions.

The chromatographic fractions and resin glycosides from 'Regal' periderm were tested only in the FOB bioassay, because the difficulty in obtaining these precluded extensive testing in this preliminary study, and FOB is one of the most important fungal pathogens of sweetpotatoes. Fraction three, which contains the periderm resin glycosides, accounted for most of the inhibitory activity in the seed germination and root growth bioassays used to isolate the periderm substances contributing to sweetpotato allelopathy (Harrison and Peterson, 1993; Peterson and Harrison, 1991). Fraction three was not as inhibitory in the FOB bioassay as fraction one, which was the least polar fraction (Table 2). Although the struc-

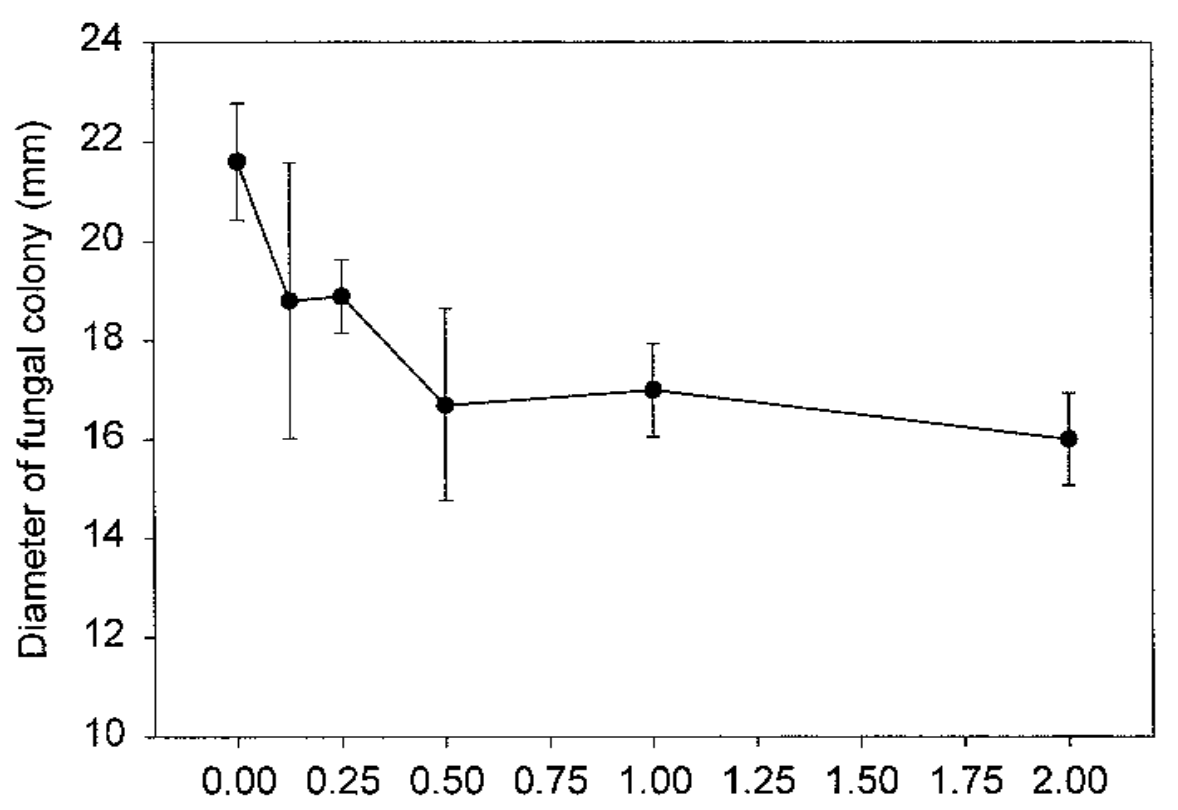

\section{Glycoside conc. ( $\mathrm{mg} \cdot \mathrm{mL}^{-1}$ )}

Fig. 1. Diameter of colonies of Fusarium oxysporum f. sp. batatas in response to 'Regal' sweetpotato periderm glycosides in potato dextrose agar medium. Bars are SD of the means.

Table 3. Diameter of colonies of four fungi that cause sweetpotato storage root rots in response to combined methanol and 50\% methanol extracts ${ }^{z}$ of the periderm of 10 sweetpotato clones in potato dextrose agar medium.

\begin{tabular}{lcccc}
\hline \hline $\begin{array}{l}\text { Sweetpotato } \\
\text { clone }\end{array}$ & \multicolumn{4}{c}{ Diameter of colony $(\mathrm{mm})$} \\
\cline { 2 - 5 } Control & FOB $^{\mathrm{y}}$ & $\mathrm{FS}$ & $\mathrm{LT}$ & $\mathrm{RS}$ \\
PI 399163 & $16.8 \mathrm{a}^{\mathrm{x}}$ & $16.1 \mathrm{a}$ & $21.6 \mathrm{a}$ & $27.1 \mathrm{a}$ \\
Tinian & $15.1 \mathrm{~b}$ & $13.7 \mathrm{~b}$ & $10.1 \mathrm{~b}$ & $27.1 \mathrm{a}$ \\
SC 1149-19 & $14.6 \mathrm{~b}$ & $13.3 \mathrm{~b}$ & $9.5 \mathrm{~b}$ & $25.3 \mathrm{a}$ \\
Jewel & $13.3 \mathrm{c}$ & $11.9 \mathrm{~cd}$ & $8.5 \mathrm{bc}$ & $23.1 \mathrm{~cd}$ \\
Centennial & $13.1 \mathrm{~cd}$ & $13.0 \mathrm{~b}$ & $9.7 \mathrm{~b}$ & $23.1 \mathrm{~cd}$ \\
Travis & $13.1 \mathrm{~cd}$ & $12.3 \mathrm{c}$ & $7.3 \mathrm{~cd}$ & $22.5 \mathrm{~d}$ \\
Beauregard & $12.4 \mathrm{~d}$ & $11.4 \mathrm{~d}$ & $9.5 \mathrm{~b}$ & $24.3 \mathrm{bc}$ \\
Regal & $10.9 \mathrm{e}$ & $10.3 \mathrm{e}$ & $6.5 \mathrm{~d}$ & $21.0 \mathrm{e}$ \\
Sumor & $10.0 \mathrm{f}$ & $6.5 \mathrm{f}$ & $2.4 \mathrm{ef}$ & $19.6 \mathrm{f}$ \\
Excel & $8.1 \mathrm{~g}$ & $6.8 \mathrm{f}$ & $4.0 \mathrm{e}$ & $20.0 \mathrm{ef}$ \\
Excl & $7.9 \mathrm{~g}$ & $5.5 \mathrm{~g}$ & $1.5 \mathrm{f}$ & $16.4 \mathrm{~g}$ \\
\hline
\end{tabular}

${ }^{2}$ Extracts were tested at concentrations equivalent to periderm extracted at 50, 50, 10 , and $25 \mathrm{mg} \cdot \mathrm{mL}^{-1}$ for FOB, FS, LT, and RS, respectively.

${ }^{\mathrm{y}} \mathrm{FOB}=$ Fusarium oxysporum $\mathrm{f}$. sp. batatas, $\mathrm{FS}=$ Fusarium solani, $\mathrm{LT}=$ Lasiodiplodia theobromea, $\mathrm{RS}=$ Rhyzopus stolonifer .

${ }^{\times}$Mean separation within columns by Duncan's multiple range test at $P \leq 0.05$. 
ture of the resin glycosides has not been elucidated, their fatty acid and sugar components and their chromatographic profile (Peterson et al., 1998) suggests the presence of several isomers that are similar in structure to the resin glycoside, tricolorin, which was isolated from the related species, Ipomoea tricolor (Coc.) by Anaya et al. (1990). The lack of concentration response (Fig. 1) indicates that the resin glycosides in 'Regal' periderm that were the most important constituents in allelopathy (Peterson and Harrison, 1991) and insect antibiosis (Peterson et al., 1998) are not the most active FOB-inhibiting components in the periderm. Interestingly, the differences between clones in fungicidal activity of the periderm extracts (Table 3) closely paralleled their differences in resin glycoside contents (Peterson et al., 1999, and unpublished data). This suggests that the less polar fungicidal components are in some way linked to the resin glycosides, perhaps as products of the same metabolic pathway. Further studies are planned to determine the effect of resin glycosides and other periderm components on the other fungi and to isolate the most inhibitory periderm constituents.

The differences in fungicidal activity of periderm extracts between the clones evaluated suggest that periderm components may contribute to cultivar differences in resistance to fungal root diseases. However, published information on the response of sweetpotato clones to root diseases caused by these fungi, other than wilt and stem canker caused by Fusarium oxysporum is limited. At this point, the role of periderm components in disease resistance cannot be determined. While the most inhibitory clones, 'Beauregard', 'Excel', 'Regal', and 'Sumor', are considered to be disease resistant (Dukes et al., 1987; Jones et al., 1985, 1989; Rolston et al., 1987), one of the least inhibitory, 'Tinian', is also considered to be resistant (Steinbauer, 1948). Apparently, factors other than fungicidal periderm components can contribute to resistance.

\section{Literature Cited}

Anaya, A.L., M.R. Calera, R. Mata, and R. PeredaMiranda. 1990. Allelopathic potential of com- pounds isolated from Ipomoea tricolor Cac. (Convolvulaceae). J. Chem. Ecol. 16:2145-2152. Campbell, T.M. and W.W. Collins. 1987. Fusarium solani root rot resistance in sweetpotato. J. Amer. Soc. Hort. Sci. 112:386-389.

Clark, C.A., P.D. Dukes, and J.W. Moyer. 1992. Diseases, p. 88-105. In: A. Jones and J.C. Bouwkamp (eds.). Fifty years of collaborative sweetpotato research 1939-1989. S. Coop. Serv. Bul. 369.

Clark, C.A. and M.W. Hoy. 1994. Identification of resistance in sweetpotato to Rhizopus soft rot using two inoculation methods. Plant Dis. 78:1078-1082.

Clark, C.A., A. Lawrence, and F.A. Martin. 1981. Accumulation of furanoterpenoids in sweet potato tissue following inoculation with different pathogens. Phytopathology 71:708-711.

Clark, C.A. and J.W. Moyer. 1988. Compendium of sweet potato diseases. APS Press, Amer. Phytopathol. Soc., St. Paul, Minn.

Clark, C.A., W.M. Randle, and C.S. Pace. 1986. Reactions of sweet potato selections to Fusarium root and stem canker caused by Fusarium solani. Plant Dis. 70:869-871.

Collins, W.W. and L.W. Nielson. 1976. Fusarium wilt resistance in sweetpotato. Phytopathology 66:489-493

Dukes, P.D., M.G. Hamilton, A. Jones, and J.M. Schalk. 1987. 'Sumor' a multi-use sweet potato. HortScience 22:170-171.

Gapasin, R.M., R.B. Valdez, and E.M.T. Mendoza. 1988. Phenolics involved in sweetpotato resistance to Meloidogyne incognita and $M$. javanica. Ann. Trop. Res. 10:63-73.

Harrison, H.F., Jr. and J.K. Peterson. 1993. Sweetpotato periderm components inhibit yellow nutsedge (Cyperus esculentus) growth. Weed Technol. 8:168-171.

Hyodao, H. I. Uritani, and S. Akai. 1969. Production of furanoterpenoids and other compounds in sweet potato tissue in response to infection by various isolates of Ceratocystis fimbriata. Phytopathol. Z. 65:332-340.

Jenkins, P.D. 1981. Differences in the susceptibility of sweet potatoes (Ipomoea batatas) to infection by storage fungi in Bangladesh. Phytopathol. Z. 102:247-256.

Jones, A., P.D. Dukes, J.M. Schalk, and M.G. Hamilton. 1989. 'Excel' sweet potato. HortScience 24:171-172.

Jones, A., P.D. Dukes, J.M. Schalk, M.G. Hamilton, M.A. Mullen, R.A. Baumgardner, D.R. Paterson, and T.E. Boswell. 1985. 'Regal' sweetpotato. HortScience 20:781-782.
Kim, W.K. and I. Uritani. 1974. Fungal extracts that induce phytoalexins in sweet potato roots. Plant Cell Physiol. 15:1093-1098

Peterson, J.K. and H.F. Harrison, Jr. 1991. Isolation of a substance from sweetpotato that inhibits seed germination. J. Chem. Ecol. 17:943-951.

Peterson, J.K. and H.F. Harrison, Jr. 1992. Chemical factors involved in sweetpotato pest resistance and allelopathy, p. 263-272. In: W.A. Hill, C.K. Bonsi, and P.A. Loretan (eds.). Sweetpotato Technology for the $21^{\text {st }}$ Century. Tuskegee Univ., Tuskegee, Ala.

Peterson, J.K., H.F. Harrison, Jr., and A.E. Muckenfuss. 1998. Sweetpotato [Ipomoea batatas (L.)] glycosides: Evidence of antibiosis effects in the diamondback moth, Plutella xylostella L. (Lepidoptera: Plutellidae). Allelopathy J. 5:43-52.

Peterson, J.K., H.F. Harrison, Jr., and M.E. Snook. 1999. Comparison of three parameters for estimation of allelopathic potential in sweetpotato [Ipomoea batatas (L.) Lam.] germplasm. Allelopathy J. 6:201-208.

Rolston, L.H., C.A. Clark, J.M. Cannon, W.M. Randle, E.G. Riley, P.W. Wilson, and M.L. Robbins. 1987. 'Beauregard' sweet potato. HortScience 22:1338-1339.

Schneider, J.A., J. Lee, Y. Naya, K. Nakanishi, K. Oba, and I. Uritani. 1984. The fate of the phytoalexin ipomeamarone: Furanoterpenes and butenolides from Ceratocystes fimbriata infected sweetpotato tissue. Phytochemistry 23:759-764.

Steinbauer, C.E. 1948. A sweetpotato from Tinian Island highly resistant to fusarium wilt. Proc. Amer. Soc. Hort. Sci. 52:304-306.

Steinbauer, C.E. and L.J. Kushman. 1971. Sweet potato culture and diseases. Agr. Hdbk. 388 Agr. Res. Serv., U.S. Dept. Agr., Washington, D.C.

Uritani I. 1967. Abnormal substances produced in fungus contaminated foodstuffs. J. Assn. Offic. Anal. Chem. 50:105-114.

Uritani, I. and T. Akazawa. 1954. Antibiotic effect on Ceratostomella fimbriata of ipomeamarone, an abnormal metabolite in black rot of sweetpotato. Science 121:216-217.

Uritani, I. and M. Myano. 1955. Derivatives of caffeic acid in sweetpotato attacked by black rot. Nature 175:812

Wilson, B.J. 1973. Toxicity of mold-damaged sweetpotatoes. Nutr. Rev. 31:73-78.

Wilson, B.J., M.R. Boyd, T.M. Harris, and D.T.C. Yang. 1971. A lung edema factor from mouldy sweet potatoes (Ipomoea batatas). Nature 231:52-53. 